\title{
Does Woman Director Matters in Performance and Risk? A Study in ASEAN Banking Firms
}

\author{
Maulida Nurul Innayah ${ }^{1}$, Bima Cinintya Pratama ${ }^{2}$, Akhmad Darmawan $^{3}$, Dwi Winarni ${ }^{4}$, \\ Prita Esita ${ }^{5}$ \\ \{nanamaulida@gmail.com ${ }^{1}$ \}
}

Faculty of Economics and Business, Universitas Muhammadiyah Purwokerto, Indonesia ${ }^{12345}$

\begin{abstract}
This study examines the effect of woman director on firm performance and risk in ASEAN banking firms. The data used in this study was obtained from Bloomberg and OSIRIS database and also firm's annual reports during 2014-2018 and conducted on five countries in ASEAN, namely Indonesia, Philippines, Malaysia, Singapore, and Thailand. The final sample used in this study consists of a total of 375 observations. This study uses panel data regression model analysis, ie. fixed effect regression and random effect regression. The results showed that woman director has a positive and significant effect on firm performance. The results also showed that woman director has a negative and significant effect on risk. This results indicate that the presence of woman director can improve firm performance and reduce risk.
\end{abstract}

Keywords: Woman Director, Firm Performance, Risk.

\section{Introduction}

The role of woman in the firm, especially in top management, has received much attention. For woman, occupying a position in top management is not easy. In the early 2000s, a term of glass ceiling was commonly used to discuss the phenomenon of role inequality between men and woman in the work environment. This phenomenon can be explained by gender role theory which explains that gender creates expectations of how men and woman should behave and then affects perceptions about them at work [1] [2]. However, according to expectancy violation theory, women who are not expected to be better than men at work, if they can do the same work with men, will be given more appreciation.

In line with expectancy violation theory, several studies have found that woman can benefit from the presence of agentic behavior that they do. For example, Post et al. [3] found that women who were considered innovative were considered better than men who were equally innovative. These women are considered biased towards agentic behavior that can benefit the group as a whole. This is in line with Eagly and Carli [4] who argue that if women can occupy positions as directors, then women do have the skills and intelligence as directors.

With the existence of empirical and theoretical evidence, several countries make regulations about the existence of woman in the firm. In 2006, Norway was the first country in the world to apply a gender quota to directors by deciding that a minimum of 40 percent of directors must be women [5]. In addition to Norway, regulations regarding the importance of women in top management are also carried out in ASEAN, including Indonesia [6]. According to Staffing Industry Analysts [7], several ASEAN countries have begun implementing gender quotas. In 2016, Malaysia has imposed a 30 percent quota for women who are in directors and Singapore has considered increasing gender diversity in directors. 
Although most countries in Asia do not have gender quota regulations, according to Staffing Industry Analysts [8], Asian companies have a significant number of woman director and their numbers continue to increase. According to a survey from Korn Ferry and the National University of Singapore Business School, the average number of women in directors increased from $8 \%$ to $9.4 \%$. A similar study also showed that the number of women in directors was $35.5 \%$ in Norway, $22.8 \%$ in the UK, and $19.2 \%$ in the US. The survey includes 100 companies that have the largest market capitalization, including ASEAN countries such as Indonesia, Malaysia and Singapore.

Previous research has discussed a lot about the role of woman in managing firms, one of them being directors. Based on their characteristics, woman has the skill and intelligence as director [4]. The important aspect that need to be considered in the firm sustainability are performance and risk. Performance and risk have trade-offs that need to be managed properly. Thus, the role of women directors in managing performance and risk becomes important.

Previous researches have discussed about the role of women in firm, one of them is being director. Based on their characteristics, woman has the skill and intelligence as director [4]. The important aspects that need to be considered in the firm sustainability are firm performance and risk. Performance and risk have trade-offs that need to be managed properly. Thus, the role of women directors in managing performance and risk becomes important.

Based on the explanation above, researchers are interested to examine whether the existence of woman directors can improve firm performance and reduce risk. This is because most of the previous studies only examined one country as an institutional setting. So that researchers are motivated to use the settings of countries in ASEAN to provide an overview of the effect of woman director on firm performance and risk in countries in emerging markets and provide an overview of firms in ASEAN.

\section{Literature Review}

\subsection{Glass Ceiling}

The glass ceiling first appeared in the United States, it describes a situation where woman in an organization can see their senior position higher, but have difficulty reaching that position. The presence of an invisible barrier that prevents vertical mobility from woman can be explained by the glass ceiling. For example, Carly Fiorina, who was the chief executive officer (CEO) at Hewlett-Packard until 2005 experienced this. Early in his career as the only woman manager, he discovered that there was an attempt by his male colleagues that they were trying to make the ranks contain only men [9].

Kumra and Vinnicombe [10] shows gender biases in the career structure and promotion systems that are studied in companies and professional organizations where woman is often overlooked on key tasks because of assumptions about what can and what woman cannot do. This phenomenon occurs mostly in organizations that have progressive employment policies that illustrate the complexity of what can hold woman back in terms of their career development and progress. In short, when employers only have an organizational culture that seems to be resistant to women workers, this will arise.

\subsection{The Role of Woman in Leadership: Theoretical Perspectives}

Gender creates expectations about how men and woman should behave and this will then influence people's perceptions at work [1] [2]. This argument can be explained by gender role 
theory. Gender role theory explains that gender automatically activates stereotypical expectations which will assume that men are better in leadership positions than woman. Because empirical evidence shows that woman and men differ slightly in their effectiveness evaluation of leadership [11], the tendency for men to be considered more appropriate to fill leadership positions relative to woman is a clear subjective gender bias [12] [13].

In contrast to gender role theory, expectancy violation theory explains that individuals who carry out positive behaviors that are not expected of them, based on their stereotypes, will be considered more positive when they succeed in positive behavior, compared to individuals who are expected to do [14]. Therefore, based on the perspective of expectancy violation theory, woman who engage in agentic behavior should be more positive than men who engage in the same behavior. The importance of agentic behavior for leadership emergence, and coupled with the greater perceptual credit that woman receive in engaging in agentic behavior that is relevant to the team, woman who are actively involved in this behavior should be able to emerge as leaders who are more recognized than men who engage in behavior the same, so that it will be heard more as a leader.

\subsection{Woman Director, Corporate Governance, Firm Performance and Risk}

The role of directors in controlling the firm can be seen from the role of directors in optimizing firm value by increasing performance and reducing risk. Within the framework of the corporate governance mechanism, optimizing the role of directors in controlling and managing the firm can be done through the mechanism of regulating the role and behavior of directors (board governance), including setting the composition of directors within the firm. In order to improve performance and reduce risk, the implementation of board governance in companies must be better. One important issue regarding the implementation of board governance is the issue of diversity of directors, especially regarding the diversity of gender aspects.

The resource dependence theory which was state by Pfeffer and Salancik [15] provides a theoretical basis for diversity in directors. Resource dependence theory believes that it can connect companies with other external organizations to overcome environmental dependency. There are four benefits to the existence of external relations according to Pfeffer and Salancik [15], namely: the provision of resources such as information and expertise, the creation of communication channels with important compilers for the firm, providing commitment support from important organizations or groups in the external environment, and creating legitimacy for firm in the external environment.

Hillman et al. [16] develop resource dependence theory and show that diversity in directors will provide useful and different resources for companies. According to resource dependence theory, the diversity in directors will bring unique information that can help better decision making [17]. Therefore, more diverse directors will provide more valuable resources, which can result in better firm performance [17]. Human capital theory complements several concepts related to the diversity of boards originating from RDT. Terjesen, Sealy, and Singh [18] show that HCT discusses the role of knowledge, experience, and skills possessed by someone that can be used for the benefit of an organization.

In this research, diversity of directors is seen from gender. Terjesen, Sealy, and Singh [18] revealed that the existence of gender differences in directors would make companies have unique human capital. The researcher believes that the diversity of human resources within the board of directors that causes these resources to be unique, can influence decisions in the organization, which have an impact on performance and risk. 


\subsection{Woman Director and Firm Performance}

Expectancy violation theory states that individuals who perform positive behaviors that are not expected of them, based on their stereotypes, will be considered more positive when they succeed in positive behavior, compared to individuals who are expected to do so [14]. Therefore, based on the perspective of expectancy violation theory, woman who engage in agentic behavior should be more positive than men who engage in the same behavior. This indicates that woman has the skill and intelligence as director [4].

Companies with a higher proportion of woman in top management were able to achieve higher profits, according to research conducted on 21,980 companies in 91 countries by the Peterson Institute for International Economics [5]. This is in line with a meta-analysis study conducted by Post and Byron [19] which examined not only whether women executives and directors can affect firm performance, but also what conditions determine the relationship and also how women executives and directors affect the financial performance.

Using upper echelons theory, Post and Byron [19] argue that women in directors due to differences in knowledge, experience, and values are able to shape and influence the process and results of decision making and activities carried out by directors which will ultimately affect firm performance. The findings from the meta-analysis show that firms with more woman director are more likely to have better financial (accounting) and market performance. The study also found additional results that companies with executives and directors of women had better financial/accounting performance in companies in countries with better stakeholder protection.

In addition, Post and Byron [19] also found that companies with woman executives and directors have better market performance in countries with a higher gender balance/equality. Luckerath-Rovers [20] showed that companies with top management membership and woman director consistently proved to perform better than companies that did not have woman director. Adams and Ferreira [21] showed that women directors show greater diligence in monitoring and taking positions on committees that have responsibilities in reporting and transparent reporting quality, such as audit committees and corporate governance. Adams, Gray, and Nowland [22] argue that woman director show more independent thinking. The study further showed that investors appreciated the addition of woman director in directors.

Woman director will produce more appropriate considerations and discuss tighter issues that are often deemed unacceptable by male directors [23]. Women morally can contribute with a fresh perspective to solve complex problems, which can reduce the formulation of information strategies [24]. According to Hillman et al. [25] the presence of women in directors can also support the development of good communication and the establishment of better relationships between companies and different external stakeholder groups. Discussions carried out by directors are more appropriate and better communication can increase the supervisory ability of directors [18]. The presence of women in directors leads to the increasing of total assets, annual meetings, number of directors and performs better (expressed by Tobin's $Q$ and return on assets) [26].

Deszo and Ross [27] found that the presence of women in top management can improve firm performance. Firms with woman director perform better than companies without woman director [20]. The percentage of women in directors can increase accounting returns [19]. Women in directors can improve financial performance (as measured by return on assets and return on sales) and with ethical and social adjustments will increase firm value [28]. Firms with woman director perform better than companies without woman director [20]. Based on the description above, the hypotheses proposed in this study are as follows:

H1: Woman director has positive effect on firm performance in ASEAN banking firms. 


\subsection{Woman Director and Risk}

Previous studies showed that woman director is able to improve performance, while some literature also shows the importance of gender as a risk-related decision-making factor. One of the most prominent attributes of woman is their risk aversion [29]. Byrnes et al. [30] conducted a meta-analysis of 150 articles in the field of psychology which found that the average woman significantly avoided risk more than men. However, they also suggest that gender differences in risk taking tend to depend on the specific context or task under study.

Research in economics confirms that woman shows greater risk aversion and lower trust. Due to the conservative nature of woman, woman director can correct bias in important decisions especially those related to strategic oversight and risk by thinking about problems and detailing solutions, so woman is often considered more conservative than men [31] [32]. Bellucci et al. [33] and Beck et al. [34] focus on the implications of gender differences in the banking context. Bellucci et al. [33] found that woman credit employee avoid risk more than male credit employees and limit the availability of credit to new borrowers. Beck et al. [34] shows that loans handled by woman credit employee have significantly reduced the failure rate.

In the banking sector in Indonesia, Setiyono and Tarazi [35] found that woman director can reduce risk. The study further explained that it might not be because of differences in avoidance of gender risk, but rather because of preference for risk in a homogeneous environment, ie there is a higher risk in less diverse directors [36]. Based on the description above, the hypotheses proposed in this study are as follows:

H2: Woman director has negative effect on risk in ASEAN banking firms.

\section{Methods}

\subsection{Sample}

The sample in this study obtained from Bloomberg and OSIRIS database and also annual report. The sample of this study are the firms engaged in high technology industries. The countries selected as the sample are the countries in Southeast Asia that have complete data namely Indonesia, Philippines, Malaysia, Singapore, and Thailand.

The initial sample consists of 89 firms with years of observations during 2014 to 2018 . Due to incomplete data on the variables selected, the final sample used in this study is amounted to 75 firms with a total of 375 firm-year observations. Table 1 shows the final sample used and its distribution by country.

Table 1. Sample Distribution by Countries

\begin{tabular}{lcc}
\hline Country Name & Number of Firm & Number of Observation \\
\hline Indonesia (IN) & 40 & 200 \\
Philippines (FL) & 13 & 65 \\
Malaysia (ML) & 9 & 45 \\
Singapore (SN) & 4 & 20 \\
Thailand (TH) & 9 & 45 \\
\hline Total & 75 & 375 \\
\hline
\end{tabular}

\subsection{Variables}

a) Independent Variable The Composition of Woman Director (WomanDir) 
The composition of woman director (WomanDir) is proxied with the proportion of the woman directors' composition calculated by the formula:

\section{Proportion of Woman Director Composition $=$ Number of Woman in the Board} of Directors / Number of Members of the Board of Directors

\section{b) Dependent Variable}

\section{Firm Performance (FirmPerf)}

Same with the studies from Firer and Williams [37], Chen et al. [38] and Mondal dan Ghosh [39], the firm performance is measured by ROA (return on assets). ROA measured by the following equation:

$$
\text { ROA }=\text { Profit before tax } / \text { Average total assets. }
$$

\section{Credit Risk (Risk)}

Same with the study from Gosh dan Maji (2014), credit risk measured by: Credit

\section{Risk $=$ Net non-performing loans $/$ Net advances}

\section{c) Control Variable}

Board Size (BoardSize)

Board Size (BoardSize) is proxied with the number of directors in the board of directors.

\section{Bank Size (BankSize)}

Bank Size (BankSize) is measured by natural logarithm of bank total asset at year t.

\section{Net Interest Margin (NIM)}

Net interest margin(NIM) is measured by dividing revenue from net Interest with total earning assets.

\section{Loan to Asset Ratio (LTAR)}

Loan to Asset Ratio is measured by dividing Loan and total asset.

\subsection{Regression Model}

This study uses panel data regression model analysis, namely fixed effect or random effect regression. This study uses Hausman test to find out which is the most suitable panel data regression model between fixed effect and random effect regression [40]. The hypotheses testing in this study were using six equation models. The equation models used to test all of the hypotheses in this study are as follows:

Model 1. Woman Director on Firm Performance

FirmPerf $=\beta_{0}+\beta_{1}$ WomanDir $+\beta_{2}$ BoardSize $+\beta_{3}$ BankSize $+\beta_{4} N I M$

$$
+\beta_{5} L T A R+\varepsilon_{t}
$$

Model 2. Woman Director on Credit Risk

Risk $=\beta_{0}+\beta_{1}$ WomanDir $+\beta_{2}$ BoardSize $+\beta_{3}$ BankSize $+\beta_{4} N I M+\beta_{5}$ LTAR

$$
+\varepsilon_{t}
$$


Where:

$\begin{array}{ll}\text { FirmPerf } & =\text { Firm Performance } \\ \text { Risk } & =\text { Credit Risk } \\ \text { WomanDir } & =\text { Proportion of Woman Director } \\ \text { BoardSize } & =\text { Control Variable of Board Size } \\ \text { BankSize } & =\text { Control Variable of Bank Size } \\ \text { NIM } & =\text { Control Variable of Net Interest Margin } \\ \text { LTAR } & =\text { Control Variable of Loan to Asset Ratio } \\ \varepsilon_{\mathrm{t}} & =\text { error term }\end{array}$

\section{Result And Discussion}

\subsection{Descriptive Statistics}

Table 2 showed the descriptive statistics of the variables used in this study. The variable FirmPerf has a mean value of 1.305053. Risk variable has a mean value of .931906 . The Board of Directors in the study sample averaged seven people, while woman director numbered two of the total number of directors. Overall, the descriptive statistics of each variable can be seen in Table 2 below.

Table 2. Descriptive Statistics of Selected Variables

\begin{tabular}{lllll}
\multicolumn{5}{c}{ Table 2. Descriptive Statistics of Selected Variables } \\
\hline Variable & Max & Min & Mean & Std. Dev. \\
\hline FirmPerf & 4.04 & -9.72 & 1.305053 & 1.299689 \\
Risk & 0.931906 & 0 & 0.0435395 & 0.1439848 \\
WomanDir & 0.75 & 0 & 0.1718421 & 0.1901163 \\
Board_Size & 14 & 3 & 6.647368 & 2.685818 \\
Bank_Size & 20.76 & 13.86 & 17.10168 & 1.815258 \\
NIM & 11.65 & 0.56 & 5.257316 & 1.893569 \\
LTAR & 2.36 & 0.36 & 0.8732105 & 0.1364427 \\
\hline
\end{tabular}

\subsection{Hypotheses Testing}

Table 3 shows the results of hypothesis testing.

Table 3. the results of hypothesis testing

\begin{tabular}{|c|c|c|c|c|}
\hline \multirow{3}{*}{$\begin{array}{l}\text { Independent } \\
\text { Variable }\end{array}$} & \multicolumn{2}{|c|}{ Model 1} & \multicolumn{2}{|c|}{ Model 2} \\
\hline & \multirow{2}{*}{$\begin{array}{l}\text { ROA } \\
\text { Coeff }\end{array}$} & \multirow[b]{2}{*}{$\mathbf{T}$} & \multicolumn{2}{|c|}{ Risk } \\
\hline & & & Coeff & $\mathbf{T}$ \\
\hline Const & 8.820061 & 1.61 & -0.5412771 & $-2.89 * * *$ \\
\hline WomanDir & 1.51278 & $1.69^{*}$ & -0.0933746 & $-1.75^{*}$ \\
\hline Board_Size & 0.0890275 & 0.96 & -0.0189699 & $-2.19 * *$ \\
\hline Bank_Size & -.5454455 & $-1.77 *$ & 0.041907 & 3.28 \\
\hline $\mathrm{Nim}^{-}$ & 0.2297902 & $2.36 * *$ & -0.0083873 & -1.47 \\
\hline Ltar & -.2826457 & -0.43 & 0.0622719 & 0.83 \\
\hline $\mathbf{F}$ & \multicolumn{2}{|c|}{2.54} & \multicolumn{2}{|c|}{17.79} \\
\hline Prob $>$ F & \multicolumn{2}{|c|}{0.0307} & \multicolumn{2}{|c|}{0.0032} \\
\hline
\end{tabular}

Notes: $* * *$ indicates significance at the $1 \% ; * *$ indicates significance at the $5 \% ; *$ indicates significance at the $10 \%$ 
In general, the results are consistent with Resource dependence theory and Human Capital Theory that explain about the existence of board diversity. The diversity of the board can maximize the decision-making process that leads to better performance.

Hypothesis 1 testing aims to answer research questions whether woman director strengthen has positive effect on firm performance. Table 3 shows the results of hypothesis testing in this study. Hypothesis 1 testing showed significant positive effect of WomanDir and FirmPerf variables with coefficient of -1.69 at $10 \%$ significance level. Therefore, hypothesis 1 which states that woman director has positive effect on firm performance, is supported.

The result is consistent with previous studies examining the effect of the proportion of woman director on firm performance has found that woman director can improve firm performance. Gender diversity in board will result in more precise deliberation and discussion of tighter issues often considered unacceptable to male directors [23]. Woman can morally contribute with a fresh perspective to solve complex problems, which can reduce the formulation of information strategies [24]; supporting the development of good communication and the establishment of better relationships [25]. Several studies have found that the presence of woman in board of director can improve firm performance [27] [20]; [19] [28].

Hypothesis 2 testing aims to answer research questions whether woman director has negative effect on risk. Table 3 shows the results of hypothesis testing in this study. Hypothesis 2 testing showed significant negative effect of WomanDir and Risk variables with coefficient of -1.75 at $10 \%$ significance level. Therefore, hypothesis 2 which states that woman director has negative effect on risk, is supported.

The result is consistent with previous studies that examining the effect of the proportion of woman director on corporate risk. The result has found that women directors can reduce risk. Bellucci et al. [33] found that women credit officers were more risk averse than male credit officers and limited the availability of credit to new borrowers. Besides that, research from Beck et al. [34] indicates that loans handled by women credit officers have significantly reduced the failure rate.

\section{Conclusions, Implications And Suggestions}

\subsection{Conclusions}

This study examined the effect woman director on performance and risk in ASEAN banking firm during the period of 2014-2018. The first objective of this study was to examine the positive effect between woman director and firm performance in ASEAN banking firm. The results showed that woman has a positive effect on firm performance. It means that the existence of woman director can improve firm performance because of their governance role.

The first objective of this study was to examine the positive effect between woman director and firm performance in ASEAN banking firm. The results showed that woman has a positive effect on firm performance. It means that the existence of woman director can improve firm performance because of their governance role. The second objective of this study was to examine the negative effect between woman director and risk in ASEAN banking firm. The results showed that woman has a negative effect on firm performance. It means that the existence of woman director can reduce credit risk because of their governance role. 


\subsection{Implications and Suggestions}

This research has several implications in both theoretical and business fields. First, this research contributes in the theoretical field by adding a reference to the effect woman director on performance and risk. Second, this study contributes to the practical field by reinforcing the effect of woman director on performance improvement and risk reduction, so companies need to consider the existence of woman director as well as possible in order to encourage performance improvement and risk reduction because of their governance role. Third, this research can be a consideration for policy makers to review the need for minimum requirements in setting quotas for the existence of woman director with more attention to the experience and capabilities of the board of directors.

\section{References}

[1] Eagly, A. H. 1987. Sex differences in social behavior: A social-role interpretation. Hillsdale, NJ: Lawrence Erlbaum Associates.

[2] Eagly, A. H., Karau, S. J., \& Makhijani, M. G. 1995. Gender and the effectiveness of leaders: A meta-analysis. Psychological Bulletin, 117(1): 125-145.

[3] Post, C., DiTomaso, N., Lowe, S. R., Ferris, G. R., \& Cordero, R. 2009. A few good women: Gender differences in evaluations of promotability in industrial research and development. Journal of Managerial Psychology, 24: 348-371.Eagly, A.H. and Carli, L.L., 2003. The female leadership advantage: an evaluation of the evidence. The Leadership Quarterly, Vol. 14, pp. 807-834.

[4] Innayah, M. N. \& Pratama, B. C. 2019. Tantangan dan Kesempatan Wanita dalam Lingkungan Kerja. DERIVATIF: Jurnal Manajemen, 13(2), 8-15.

[5] Innayah, M. N., B. C. Pratama, M. M. Hanafi. 2020. The Effect of Intellectual Capital towards Firm Performance and Risk with Board Diversity as a Moderating Variable: Study in ASEAN Banking Firms. JDM (Jurnal Dinamika Manajemen) 11 (1), 26-37.

[6] Staffing Industry Analysts. 2015. Asia Pacific - Women Scarce in the Boardroom. www2.staffingindustry.com diakses pada 10 Oktober 2017.

[7] Staffing Industry Analysts. 2013. Singapore - Quotas Should be Considered to Increase Board Gender Diversity. www2.staffingindustry.com diakses pada 20 Desember 2018.

[8] Fiorina, C. 2006. Tough Choices: A Memoir, Portfolio, New York, NY.

[9] Kumra, S. and Vinnicombe, S. 2008. A study of the promotion to partner process in a professional services firm: how women are disadvantaged. British Journal of Management, 19: S65-S74, Article in special issue "Gender in management: new research directions" edited by Broadbridge, A. and Hearn, J. British Journal of Management, Vol. 19.

[10] DeRue, D. S., Nahrgang, J. D., Hollenbeck, J. R. \& Workman, K. 2012. A quasi-experimental study of after-event reviews and leadership development. The Journal of Applied Psychology, 97(5), 997-1015.

[11] Eagly, A.H. and Carli, L.L., 2007. Women and the Labyrinth of Leadership. Human Resource Management International Digest, 16 (1): 63-74.

[12] Koenig, A. M., Eagly, A. H., Mitchell, A. A. \& Ristikari, T. 2011. Are leader stereotypes masculine? A meta-analysis of three research paradigms. Psychological Bulletin, 137(4), 616-642.

[13] Lanaj, K. \& Hollenbeck, R., J. 2015. Leadership Over-emergence in Self-Managing Teams: The Role of Gender and Countervailing Biases. Academic Management Journal. 58(5), 1476-1494.

[14] Pfeffer, J. and Salancik, G. R. 1978. The external control of organizations: a resource dependence perspective. New York: Harper \& Row.

[15] Hillman, A. J., Cannella, J. A. A., and Paetzold, R. L. 2000. The resource dependence role of corporate directors: Strategic adaption of board composition in response to environmental change. Journal of Management Studies, Vol. 37: pp. 235-255. 
[16] Carter, D. A., D'Souza, F., Simkins, B.J. and Simpson, W.G. 2010. The gender and ethnic diversity of US boards and board committees and firm financial performance. Corporate Governance: An International Review, Vol. 18, No. 5, pp. 396-414.

[17] Terjesen, S., Sealy, R. dan Singh, V. 2009. Women directors on corporate boards: A review and research agenda. Corporate Governance: An International Review, Vol. 17, No. 3, pp. 320-37.

[18] Post, C. \& Bryon K. (2015). Women on boards and firm financial performance: A meta-analysis. Academy of Management Journal, 58(5), 1546-1571.

[19] Luckerath-Rovers, M. 2013. Women on boards and firm performance. Journal Management Governance, 17(2), 491-509.

[20] Adams, R. \& Ferreira, D. 2009. Women in the boardroom and their impact on governance and performance. Journal of Financial Economics, 94(2), 291-309.

[21] Adams, R., Gray, S. \& Nowland, J. 2010. Is there a business case for female directors? Evidence from the market reaction to all new director appointments. 23rd Australasian Finance and Banking Conference 2010 Paper.

[22] Huse, M., and A. Solberg. 2006. Gender related boardroom dynamics: How women make and can make contributions on corporate boards. Women in Management Review, Vol. 21, No. 2, pp. 113 30.

[23] Francoeur, C., Laballe, R., and Sinclair-Desgagne, B. 2008. Gender diversity in corporate governance and top management. Journal of Business Ethics, Vol. 81, No. 1, pp. 83-95.

[24] Hillman, A.J., Shropshire, C. dan Cannella, A.A., 2007. Organizational predictors of women on corporate boards. Academiy of Management Journal, Vol. 50, No. 4, pp. 941-952.

[25] Carter, D. A., Simkins, B.J. \& Simpson, W.G. 2003. Corporate governance, board diversity, and firm value. The Financial Review, 38(1), 33-53.

[26] Deszo, L. C. and Ross, G. D. 2012. Does female representation in top management improve firm performance? A panel data investigation. Strategic Management Journal, Vol. 33, pp. 1072-1989.

[27] Isidro, H. and Sobral, M. 2015. The Effects of Women on Corporate Boards on Firm Value, Financial Performance, and Ethical and Social Compliance. Journal of Bussines and Ethics, Vol. 132, pp. 1-19.

[28] Barsky, R. B., Juster, F. T., Kimball, M. S., dan Shapiro, M. D. 1997. Preference parameters and behavioral heterogeneity: An experimental approach in the health and retirement study. Quarterly Journal of Economics, Vol. 112, No. 2, pp. 537-579.

[29] Byrnes, J., Miller, D. \& Schafer, W. 1999. Gender differences in risk taking: a meta-analysis. Psychol Bull, 125, 367-383

[30] Wiersema, M. F., and Bantel, K. 1992. Top management demography and corporate strategic change. Academy of Management Journal, Vol. 35, pp. 91-121.

[31] Cabo, R. M., Gimeno, R., and Nieto, M. J. 2009. Gender diversity on European banks' directors: Traces of discrimination. Working Paper.

[32] Bellucci, A., Borisov, A., and Zazzaro, A. 2010. Does gender matter in bank-firm relationships? Evidence from small business lending. Journal of Banking \& Finance, No. 34, pp. 2968-2984.

[33] Beck, T., Behr, P., and Guttler, A. 2014. Gender and banking: Are women better loan officers? Review of Finance, Vol. 17, No. 4, pp. 1279-1321.

[34] Setiyono, B., dan A. Tarazi. 2018. Does Diversity of Bank Board Members Affect Performance and Risk? Evidence from an Emerging Market. In: Díaz Díaz B., Idowu S., Molyneux P. (eds) Corporate Governance in Banking and Investor Protection. CSR, Sustainability, Ethics \& Governance. Springer, Cham.Adams, R. B., \& Ferreira, D. (2004). Gender diversity in the boardroom. European Corporate Governance Institute, Finance Working Paper, 58(58).

[35] Setiyono B., dan Tarazi A. 2018. Does Diversity of Bank Board Members Affect Performance and Risk? Evidence from an Emerging Market. In: Díaz Díaz B., Idowu S., Molyneux P. (eds) Corporate Governance in Banking and Investor Protection. CSR, Sustainability, Ethics \& Governance. Springer, Cham.

[36] Adams, R. B., \& Ferreira, D. (2004). Gender diversity in the boardroom. European Corporate Governance Institute, Finance Working Paper, 58(58). 
[37] Firer, S. and Williams, S.M. 2003. Intellectual capital and traditional measures of corporate performance. Journal of Intellectual Capital, Vol. 4, No. 3, pp. 348-360

[38] Chen, M. C., J. S. Cheng and Y. Hwang. 2005. An empirical investigation of the relationship between intellectual capital and firms' market value and financial performance. Journal of Intellectual Capital, Vol. 6, No. 2, pp. 159-176.

[39] Mondal, A. dan Ghosh, K., S. 2012. Intellectual capital and financial performance of Indian banks. Journal of Intellectual Capital, Vol. 13 No. 4, pp. 515-530

[40] Gujarati, D. N. and D. C. Porter. 2009. Basic Econometrics $5^{\text {th }}$ edition. McGraw Hill/Irwin. New York, USA. 